Research Article

\title{
Utilization of Electroplating Sludge as Subgrade Backfill Materials: Mechanical and Environmental Risk Evaluation
}

\author{
Yu Zhang, Peixin Shi 1 , Lijuan Chen, and Qiang Tang $(D)$ \\ School of Rail Transportation, Soochow University, Suzhou, China \\ Correspondence should be addressed to Peixin Shi; pxshi@suda.edu.cn \\ Received 7 June 2018; Revised 1 September 2018; Accepted 17 September 2018; Published 10 October 2018
}

Academic Editor: Dingwen Zhang

Copyright (c) $2018 \mathrm{Yu}$ Zhang et al. This is an open access article distributed under the Creative Commons Attribution License, which permits unrestricted use, distribution, and reproduction in any medium, provided the original work is properly cited.

\begin{abstract}
The electroplating sludge may pose serious threat to human health and surrounding environment without safe treatment. This paper investigated the feasibility of using electroplating sludge as subgrade backfill materials, by evaluating the mechanical properties and environmental risk of the cement-coal fly ash solidified sludge. In this study, Portland cement and coal fly ash are used to solidify/stabilize the sludge. After curing for 7, 14, and 28 days, the stabilization/solidification sludge specimens were subject to a series of mechanical, leaching, and microcosmic tests. It was found that the compressive strength increased with the increase of cement content, curing time, and the cement replacement by coal fly ash besides water content. Among these factors, the impact of water content on the compressive strength is most noticeable. It was observed that the compressive strength declined by $87.1 \%$ when the water content increased from $0 \%$ to $10 \%$. Besides, leaching tests showed that the amount of leaching heavy metals were under the standard limit. These results demonstrated utilization of electroplating sludge in subgrade backfill material may provide an alternative for the treatment of electroplating sludge.
\end{abstract}

\section{Introduction}

Electroplating industries generate the increasing amount of contaminated water, which requires treatment before being discharged to mitigate the impact on the environment [1]. However, as a product from the process of the of wastewater treatment, a great deal of highly hazardous sludge is produced [2]. Every year, about 100,000 tonnes of electroplating sludge (ES) have been generated in China [3]. ES is an extremely complex mixture that contains a huge amount of heavy metals, pathogenic microorganisms, and organic pollutants [4]. These harmful ingredients, especially various heavy metals, have serious biological toxicity and can pose serious threat to human health [5-7]. Thus, the appropriate disposal of ES is becoming more urgent for the electroplating industry and environmental engineering [8].

Solidification/stabilization (S/S) techniques are widely used in the treatment for metal-contained hazardous waste. The S/S method mixes contaminants with binders to convert the hazardous waste into the immobile and low toxic form [9]. Several binders are currently used for $S / S[10,11]$.
Portland cement is one of the mostly used binders in the S/S matrix due to its easy availability and low cost. It can readily wrap wet wastes, and its alkalinity condition decreases the solubility of many inorganic toxic or hazardous metals $[12,13]$. However, the S/S of sewage sludge by cement is affected adversely by (1) the high internal porosity of cement-solidified matrix that results in higher leaching rate, and (2) the increase in volume of the solidified matrix $[14,15]$.

Other techniques for sludge disposal are also found in the literature, for example, incorporation into coal fly ash. Coal fly ash is currently one of the most common binding supplemental materials in waste stabilization. It is mainly used in mixture with Portland cement or lime and serves as a bulking agent and a pozzolan [10]. Coal fly ash is rich in silica $\left(\mathrm{SiO}_{2}\right)$ and calcium oxide $(\mathrm{CaO})$. The $\mathrm{SiO}_{2}$ reacts with calcium hydroxide formed from the hydration process of $\mathrm{CaO}$ to produce calcium silicate hydrate [12]. The pozzolanic properties enable it to be used in some engineering applications instead of cement [16]. Incorporation of fly ash into the binder can improve the long-term durability of mixed 
cement stabilized product by decreasing the penetration of aggressive agents such as chloride ions [17]. Hardened fly ash-cement mixture, when properly designed, acts with increased strength and decreased permeability. Additionally, replacing parts of cement by fly ash can reduce the cost of production $[18,19]$.

Generally, cement-solidified products are always ultimately treated by landfilling [20]. However, the limited land area and the negative impact on environment have made it more essential to develop the effective and feasible treatment techniques [15]. Some researchers have studied the stability of cement-solidified forms disposed in landfills [21-25]. Tang et al. suggested that the leaching of heavy metals from cement-solidified products can be regarded as a $\mathrm{pH}$ dependent controlled process, and the solubility and leachability of some solidified heavy metals increased when the $\mathrm{pH}$ value decreased [15]. Accordingly, some viable alternatives of reusing the sludge containing heavy metals should be encouraged to discover, helping to decrease landfill-space consumption and save resources [26].

As a waste-to-resource technique, recycling waste sludge for geotechnical works material and incorporation into construction materials can play a significant role in sustainable natural resource use [27]. Moreover, if the utilization of waste sludge in suitable geotechnical and construction material systems can be more beneficial to the stabilization of hazardous heavy metals, it will simultaneously alleviate the environmental damages. Therefore, this current work evaluated the potential utilization of solidified electroplating sludge for subgrade backfill materials. The impacts of binder formulation (different portions of Portland cement and coal fly ash), water content, and curing time on the physical properties of the solidified sludge specimens were explored. Microstructure characteristics were investigated on specimens with different formulation of the binders. In addition, the leachability of hazardous metals from the solidified sludge was evaluated for ensuring the environmental safety. The optimum proportion of substitution for meeting technical requirement and environmental standards were also determined.

\section{Materials and Methods}

2.1. Materials. The waste sludge (Figure 1(a)), as the byproduct generated from wastewater treatment processes, was collected from a diode plant located in Suzhou, China, and its physical and chemical properties are listed in Table 1. The elemental composition of the sludge was analyzed through X-ray fluorescence spectroscopy (XRF) analysis (JSX-3400R, JEOL, Japan). As shown in Table 1, the main elements in the sludge were copper $(\mathrm{Cu})$, rhodium $(\mathrm{Rh})$, and calcium (Ca), with an average composition of 23.17, 23.22, and $25.29 \%$, respectively. The first two were directly related to the production process of diode. The $\mathrm{Ca}$ is generated during the wastewater treatment process, in which calcite is used as a coagulant agent $\left(\mathrm{CaCO}_{3}\right)$ [28]. The $\mathrm{Cu}$ is the main contamination, and the toxicity degree of $\mathrm{Cu}$ is critical.
Moisture and density were determined for select sludges. The sludge was acidic ( $\mathrm{pH} 4.8$ ), with a moisture content around $70 \%$ and a density about $1.05 \mathrm{~g} / \mathrm{cm}^{3}$. Table 1 shows the mean values of three parallel samples used in the analysis. Moisture was measured following the method described by EN 14346: 2006 [29]. Density was determined by introducing a certain amount of sludge in water and measuring the volume on exchanging with water [30].

Portland cement (PC), coal fly ash (CFA), and water were used as binding materials. The PC was purchased from a local cement plant in Suzhou, China, mainly consisting of $6-15 \%$ active additive and $85-94 \%$ cement. The CFA was supplied by a coal-fired power plant located in Anhui, China (Figure 1(b)). The physical properties and chemical compositions of the cementitious materials are summarized in Table 1. Physically, CFA is in a form of fine particles with a medium density $\left(2.9 \mathrm{~g} / \mathrm{cm}^{3}\right)$ and has a high surface area $\left(3413 \mathrm{~cm}^{2} / \mathrm{g}\right)$. The $\mathrm{pH}$ value of CFA shows alkalinity $(\mathrm{pH}=10.36)$. In terms of chemical compositions, high contents of $\mathrm{Si}$ and $\mathrm{Al}$ were observed in CFA, which was in close agreement with the results of studies in other literatures [31, 32]. Water used in this study was deionized and was prepared from tap water via distillation (RFD240NA, Advantec, Japan).

2.2. Sample Preparation. During sample preparation, the homogeneity of CFA and sludge need to be guaranteed. The sludge was grinded to aid workability of the sludge-ash-cement matrix during casting. Prior to mixture, the CFA and PC were oven dried (101-A, Leao, China) at a temperature of $105^{\circ} \mathrm{C}$ for at least 24 hours and then cooled down naturally. The designed amounts of sludge, PC, CFA, and water were mixed together manually with certain care. Table 2 lists the detailed composition of sludge-ash-cement samples. Sludge was prepared with different water, PC, and CFA amounts in order to examine the effect of the PC replacement, water content, and cement content on the mechanical and leaching properties of mixtures. The proportions of cement were 10,15 , and $20 \%$ by total weight of solid materials. In terms of PC replacement, the S/S sludge specimens were prepared with a constant binder content (PC + CFA) of 30\%, including 20\% PC + 10\% CFA (i.e., 33\% PC replacement) and 15\% cement $+15 \%$ CFA (i.e., 50\% PC replacement). In particular, the water content used in this study is the additional added amount of water that excludes moisture contained originally in the raw sludge. Specimens in the unconfined compressive strength (UCS) test were prepared with water content of 0,5 , and $10 \%$, while the water content in the leachability test was $8.5 \%$. In order to achieve sufficient cement hydration, the amount of water must be considered. Excessive water may cause the loss of effective components of cement, resulting in difficulty in forming stable and uniform cementsolidified mixtures. However, when the water is inadequate, cement-sludge mixture cannot be mixed evenly, and the effective utilization rate of cement would be reduced. After designed days of curing, the samples were tested for strength and leachability. Each test was performed on three parallel samples with the same composition. 


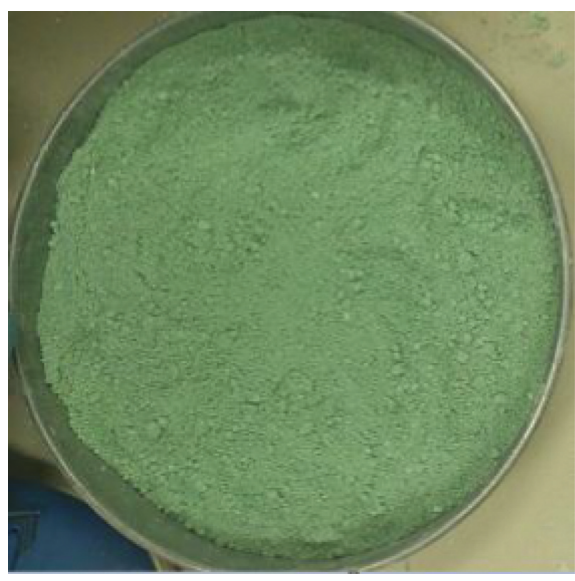

(a)

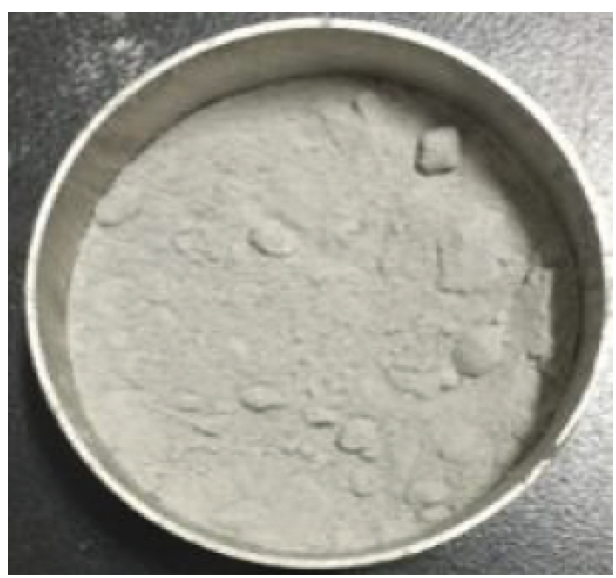

(b)

FIgUre 1: Industrial sludge and CFA used in the study.

TABle 1: Physical characteristics and chemical composition of sludge, fly ash, and cement.

\begin{tabular}{lccc}
\hline & Sludge & Coal fly ash & $\begin{array}{c}\text { Portland } \\
\text { cement }\end{array}$ \\
\hline Physical characteristics & & & \\
Moisture $(\%)$ & 70 & 20 & 0.5 \\
Density $\left(\mathrm{g} / \mathrm{cm}^{3}\right)$ & 1.05 & 2.9 & 3.18 \\
$\mathrm{pH}$ & 4.8 & 10.36 & 13 \\
Specific gravity $\left(\mathrm{g} / \mathrm{cm}^{3}\right)$ & 2.65 & 2.34 & 3.13 \\
Specific surface area $\left(\mathrm{cm}^{2} / \mathrm{g}\right)$ & 3400 & 3413 & 3550 \\
\hline Chemical composition $(\%)$ & & & \\
$\mathrm{Cu}$ & 23.17 & - & - \\
$\mathrm{Fe}$ & 2.12 & 2.95 & 2.34 \\
$\mathrm{Al}$ & 0.43 & 15.46 & 3.07 \\
$\mathrm{Ca}$ & 25.29 & 3.53 & 47.0 \\
$\mathrm{Si}$ & 0.4 & 25.24 & 9.4 \\
$\mathrm{~S}$ & 1.16 & 0.69 & 1.08 \\
$\mathrm{Zn}$ & 2.53 & - & - \\
$\mathrm{Pb}$ & 1.03 & - & - \\
$\mathrm{Mg}$ & 0.40 & - & 0.50 \\
$\mathrm{Cr}$ & 2.5 & - & - \\
$\mathrm{Mn}$ & 1.62 & - & - \\
$\mathrm{Rh}$ & 23.22 & - & - \\
$\mathrm{V}$ & 12.93 & - & - \\
$\mathrm{Sr}$ & 2.6 & - & - \\
$\mathrm{Ti}$ & - & 0.40 & - \\
$\mathrm{Na}$ & - & - & 3.19 \\
$\mathrm{~K}$ & - & - & 0.42 \\
$\mathrm{Cl}$ & - & - & 0.005 \\
\hline & & &
\end{tabular}

\subsection{Test Methods}

2.3.1. Unconfined Compressive Strength. To measure the UCS, the mixture was filled into the mold ( $4 \mathrm{~cm}$ in diameter, $8 \mathrm{~cm}$ in height). To ensure uniformity, samples were compacted in four equal layers, and each layer was dropped by rammer with the same hammer times. After that, the specimens were demolded and cured at 95\% humidity and $27^{\circ} \mathrm{C}$ temperature for 7,14 , and 28 days in a curing box (HBY-15B, Donghua, China). The UCS testing was
TABLE 2: Experimental tests carried out.

\begin{tabular}{lccccccc}
\hline \multirow{2}{*}{ Mixture } & \multicolumn{3}{c}{ Binder (\%) } & \multirow{2}{*}{ Mixture } & \multicolumn{3}{c}{ Binder (\%) } \\
& PC & CFA & Water & & PC & CFA & Water \\
\hline UCS & & & & Leaching & & & \\
1 & 15 & 0 & 5 & 1 & 0 & 0 & 0 \\
2 & 20 & 0 & 5 & 2 & 10 & 0 & 8.5 \\
3 & 30 & 0 & 5 & 3 & 15 & 0 & 8.5 \\
4 & 15 & 15 & 0 & 4 & 20 & 0 & 8.5 \\
5 & 20 & 10 & 0 & 5 & 30 & 0 & 8.5 \\
6 & 15 & 15 & 5 & 6 & 10 & 20 & 8.5 \\
7 & 20 & 10 & 5 & 7 & 15 & 15 & 8.5 \\
8 & 15 & 15 & 10 & 8 & 20 & 10 & 8.5 \\
9 & 20 & 10 & 10 & - & - & - & - \\
\hline
\end{tabular}

performed with a microcomputer-controlled electronic machine (LDS-50, Chenda, China) with a fixed strain rate of $1 \% /$ min according to ASTM D4219.

2.3.2. Leaching Test. The sample preparation for the leaching test is the same as that for the UCS test, besides the curing time being 14 days. After that, the leaching tests were carried out according to the USEPA TCLP method (method no: 1311) [33]. All the specimens were oven dried at $105^{\circ} \mathrm{C}$ for $24 \mathrm{hrs}$ and then manually crushed to $<9.5 \mathrm{~mm}$ for the TCLP. The pulverized mixture was weighed and mixed with deionized water at a liquid-to-solid ratio of 20 by weight. The $\mathrm{pH}$ value of the samples was adjusted to $2.88 \pm 0.05$ by adding $0.1 \mathrm{M}$ acetic acid, and then the samples were vibrated at $30 \mathrm{rpm}$ for $18 \mathrm{hrs}$ before passing them through $0.6-0.8 \mu \mathrm{m}$ glass fiber filters. Subsequently, the targeted heavy metal in the filtrate solution was analyzed by atomic absorption spectroscopy (AAS) (TAS-990, Persee General, China) to assess its potential leachability.

2.3.3. Microscopic Characteristics Test. The shape, size, and morphology of the S/S samples were observed through a SU8020 scanning electron microscope (SEM). During SEM, the 
samples were firstly crushed, dried at $65^{\circ} \mathrm{C}$, and then mounted on Al-stubs and gilt with $\mathrm{Au}$, with a working voltage of $15 \mathrm{kV}$.

\section{Testing Results and Discussion}

3.1. UCS. The UCS is one of the important factors affecting the solidified effect. To date, most countries do not have concrete strength index for sludge landfill, except for Germany where a minimum requirement for UCS is set at $50 \mathrm{kPa}$ $[34,35]$. Figure 2 shows that the UCS of all solidified sludge treated by the blended cement meets the acceptance criterion for landfilling. As shown in Figure 2, the UCS of solidified sludge varied depending on the PC content. For example, in the case of the mixtures containing 15,20 , and $30 \%$ of PC by weight, after 28-day curing, the UCS was $0.17,0.20$, and $0.21 \mathrm{MPa}$, respectively. It shows that, with the increase of the proportion of PC, the sludge strength increases. It is supposed that the cement hydration provides the formation of calcium silicate hydrated (C-S-H) and calcium hydroxide $(\mathrm{CH})$, which is the gels in cement responsible for strength development $[36,37]$. It can be seen from Figure 2, the UCS of the cementsludge mixtures was not obviously increased in the early stage of experiment. This may due to the presence of a large number of $\mathrm{Cu}$ atoms, which is reported to contribute to the retardation of cement hydration [38]. Cu may exist as hydroxides or interactions with calcium to form a series of complex compounds in the cement-solidified materials [39]. These detrimental compounds can wrap the binder particles and restrict further pozzolanic activity and the generation of cementitious gels. Such changes would play a negative influence on the strength of $S / S$ mixtures [40]. Figure 2 shows an unusual phenomenon that was based on the $0 \%$ water content; the UCS of the cement-solidified sludge decreased with the increasing amount of cement after 7-day and 14-day curing. This can be explained that the water required for cement hydration comes only from moisture contained originally in the raw sludge, resulting in an insufficient hydrated reaction. Some cement particles without hydration, acting as filling materials, were filled in the pores between the soil particles and even weakened the cementation between soil particles and cement hydration products, furthermore resulting in the decrease of UCS.

As can be observed in Figure 2, the UCS of the solidified matrix increases with curing time. Compared to 7 days, the 28 -day UCS of solidified mixtures with 15, 20, and 30\% of PC increases by $21.4,81.8$, and $163 \%$, respectively. The increasing strength values over time reflected the ongoing hydration reaction during which the strong adhesive products were produced, providing strong loading resistance [41]. Tang et al. concluded that the hydration reaction is more sufficient with the increase of curing time [15]. In addition, at the later hydration age, the hydration of residual cement particles may take place by the solid-state reactions and the transport of ions in the solution becomes limited $[24,42]$. It can be seen that the setting time of cement paste plays an important role in the $S / S$ process.

The adverse impact of water on strength development is given in Figure 3, where the change of relation between the

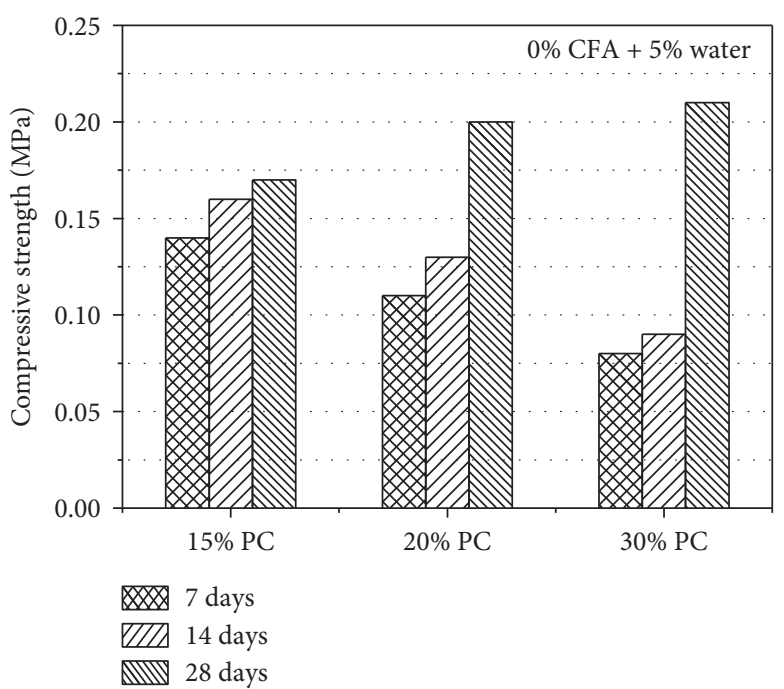

FIgURE 2: Compressive strength of solidified sludge with different amounts of PC.

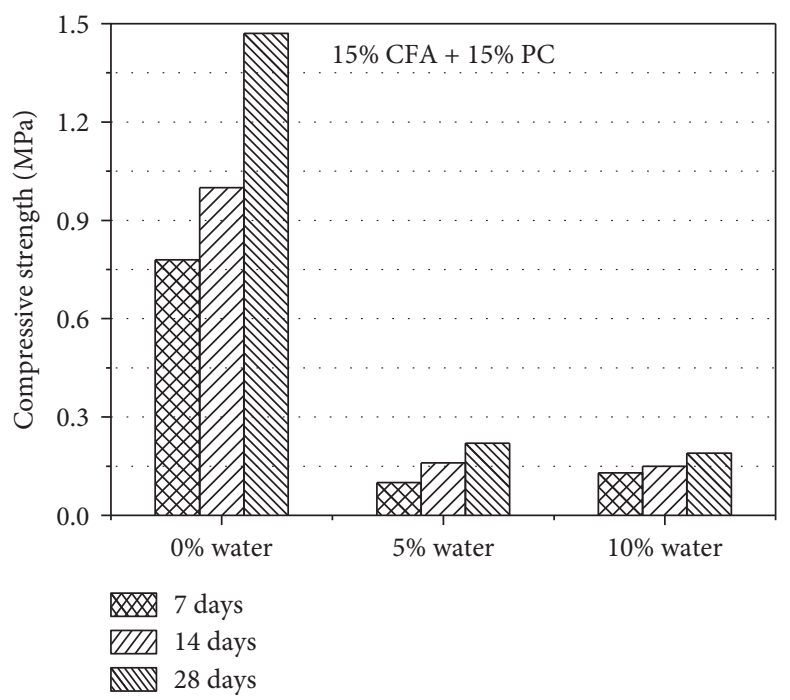

FIgURE 3: Compressive strength of solidified sludge with different water contents.

UCS and water content is depicted. Obviously, the experimental results revealed that the strength values of all time periods decreased as water content increased. For example, the UCS of cement-based matrices (water content $=0,5$, and $10 \%)$ after 28 days of solidification are 1.47, 0.22, and $0.19 \mathrm{MPa}$, respectively. Wang et al. explained that the higher water content increases the lubrication between sludge particles and reduces the friction force, which leads to the decrease of the strength [43]. Besides, the initial moisture content of the sludge is also an important factor that restricts the UCS of the solidified sludge. Table 1 shows that the initial moisture content of the sludge used in this study is $70 \%$ which is very high. It is generally very difficult to consolidate the sludge material in practice. To reduce the detrimental influence of moisture on the strength of specimens, cement 
was used as a material that, by consuming large quantities of water as a result of the pozzolanic reactions, results in a rise of the strength of the mixture [44].

Figure 4 shows the effect of CFA on the UCS of the cement-solidified mixtures. It shows that, with 0,5 , and $10 \%$ of water content, the 28-day UCS of the sludge blocks stabilized/solidified by $20 \%$ PC $+10 \%$ CFA (i.e., $33 \%$ PC replacement) and $15 \%$ cement $+15 \%$ CFA (i.e., $50 \%$ PC replacement) are (0.93 MPa, $1.47 \mathrm{MPa}),(0.1 \mathrm{MPa}, 0.22 \mathrm{MPa})$, and $(0.13 \mathrm{MPa}, 0.19 \mathrm{MPa})$, respectively. The results revealed that the PC replacement by CFA increased the mechanical strength. The hydration of CFA leads to consumption of cement hydrates and packs the pore structure already established by its own hydration product, thus helping to achieve a tighter pore structure and greater intensity for cement-based mixtures. Now in China, for the safe use of stabilized materials in the highway construction, a standard called Technical Guidelines for Construction of Highway Roadbases (JTG/T F20-2015) was established. In this highway construction technical specification, there is a specific regulation on unconfined compression strength of lime-coal fly ash stabilized, which is shown in Table 3. Based on Figure 4, it can be seen that the UCS of 14-day and 28-day solidified matrix with $0 \%$ water all can satisfy the design value $(1.1 \mathrm{MPa}$, which is required in the standard).

3.2. TCLP Results. The TCLP technique determines the pollutants' migration in a sample and the toxic degree that allows the classification of the material as "dangerous." It can be seen from Table 1 that the content of $\mathrm{Cu}$ in sludge dominates the leading position. The effect of different heavy metal ions types on cement hydration have been studied extensively in recent years. Qiao et al. investigated that copper ions leading to a high degree of inhibition in the cement hydration, indicating that the curing effect of $\mathrm{Cu}$ is worse than that of other heavy metals [45]. According to scanning electron microscope results of Wang et al., the existence of copper allows an offset in the C-S-H gel diffraction peak, and thereby decreases the crystallinity of C-S$\mathrm{H}$ [46]. Therefore, monitoring the leachability of $\mathrm{Cu}$ plays a guiding role in this research. The results of the TCLP tests are presented in Figure 5. The average leached $\mathrm{Cu}$ concentrations of untreated samples are $29.9 \mathrm{mg} / \mathrm{L}$, suggesting its high mobility in the untreated soil. Figure 5 shows the effect of the amount of PC on the leaching characterization of solidified sludge. The $\mathrm{Cu}$ leaching concentration for all stabilized samples is noticeably decreased after PC treatment. In addition, increasing PC content is found to significantly reduce the $\mathrm{Cu}$ leachability. Because of the highalkalinity environments in the cement-based matrix, these metals might exist in the form of metal hydrated phases, metal hydroxides, and calcium-metal compounds [47]. Roy and Cartledge investigated the speciation of $\mathrm{Cu}$ in the cement-solidified ES [48]. It was found that the main copper-bearing phase was a copper-hydrated phase when $\mathrm{Cu}$ was added as copper nitrate in the matrix. Cu may also exist in the form of hydroxides or react with calcium to generate complex compounds in the cement-based materials.

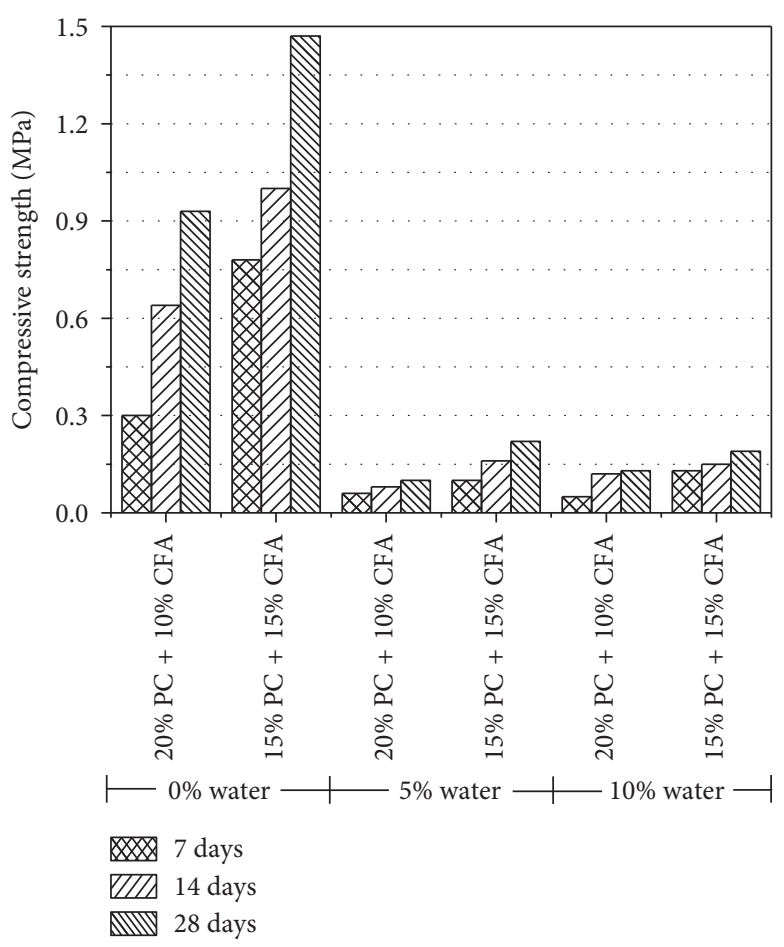

FIGURE 4: Compressive strength of solidified sludge with different contents of CFA.

In China, for the safe utilization of heavy metalcontained materials in the road construction, the relevant standard titled "Specifications for environmental impact assessment of highways" (JTG B03.2006) was established based on the characteristics of highway engineering. Considering the heavy metals in the solidified sludge will eventually permeate into the soil, the water quality evaluation in highway engineering of the this standard is the same as the standard "Soil environmental quality standard" (GB 15618-1995). So, the standard GB 15618-1995 was adopted to evaluate the acceptable leaching of the treated sludge as a roadbed material. The limit values of soil environmental quality are presented in Table 4 . The leaching characteristic of the sludge stabilized/solidified by PC + CFA is also illustrated in Figure 5. Obviously, the leaching values of the targeted heavy metal were far below the limit, although the addition of CFA increased the leaching concentration. For example, with the presence of $30 \%$ binder, all the leaching concentration of $10 \%$ $\mathrm{CFA}+20 \%$ PC $(1.3 \mathrm{mg} / \mathrm{L}), 15 \% \mathrm{CFA}+15 \%$ PC $(13.9 \mathrm{mg} / \mathrm{L})$, and $20 \% \mathrm{CFA}+10 \%$ PC $(16.1 \mathrm{mg} / \mathrm{L})$ far exceeded the leaching of $30 \%$ PC $(0.8 \mathrm{mg} / \mathrm{L})$. It may be because C-S-H gel generated by the hydration of CFA was insufficient to make up the loss of cement hydration [49]. Based on the foregoing results, CFA geopolymers solidification of heavy metals was a choice. Qian et al. considered that heavy metal ions are not only in the form of physical enclosure but also via special solidifying structures of adsorption and even bonding with matrix materials [12]. Hence, it can be firmly fixed in the geopolymers.

Scanning electron micrographs of the cement-sludge (20\% PC) and cement-fly ash-sludge mixtures (20\% PC $+10 \%$ CFA) aged 14 days are shown in Figures 6(a) and 6(b), 
TABLE 3: Unconfined compression strength of lime-coal fly ash stabilized materials (MPa).

\begin{tabular}{lcccc}
\hline Structure layer & Highway grade & Special heavy traffic & Heavy traffic & Light traffic \\
\hline \multirow{2}{*}{ Base } & Motorways and first-grade highway & $\geq 1.1$ & $\geq 1.0$ & $\geq 0.9$ \\
& Second-grade and under second-grade highway & $\geq 0.9$ & $\geq 0.8$ & $\geq 0.7$ \\
\hline \multirow{2}{*}{ Sub-base } & Motorways and first-grade highway & $\geq 0.8$ & $\geq 0.7$ & $\geq 0.6$ \\
& Second-grade and under second-grade highway & $\geq 0.7$ & $\geq 0.6$ & $\geq 0.5$ \\
\hline
\end{tabular}

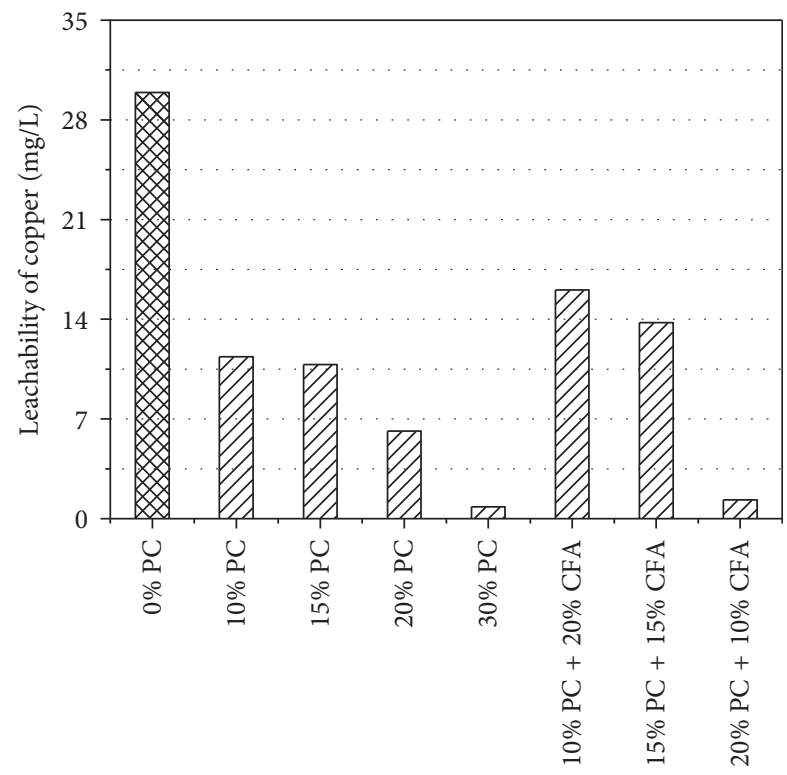

Raw sludge

ZIIJ Solidified sludge

Figure 5: TCLP leachability of solidified sludge with different binder formulations.

TABLE 4: Standard values of soil environmental quality $(\mathrm{mg} / \mathrm{L})$.

\begin{tabular}{lccccc}
\hline Heavy metals & $\begin{array}{c}\text { Grade I } \\
\text { Natural }\end{array}$ & $\mathrm{pH}<6.5$ & $\begin{array}{c}\text { Grade II }^{\mathrm{a}} \\
\mathrm{pH} \mathrm{6.5-7.5}\end{array}$ & $\mathrm{pH}>7.5$ & $\begin{array}{c}\mathrm{Grade} \mathrm{III}^{\mathrm{c}} \\
\mathrm{pH}>6.5\end{array}$ \\
\hline $\mathrm{Cu}$ (farmland) & 35 & 50 & 100 & 100 & 400 \\
$\mathrm{Cu}$ (orchard) & - & 150 & 200 & 200 & 400 \\
\hline
\end{tabular}

${ }^{a}$ Limit values for protecting natural ecology and maintaining the soil quality in the natural setting. ${ }^{b}$ Limit values for protecting agricultural productions and human health. ${ }^{c}$ Limit values for protecting the normal growth of plants.

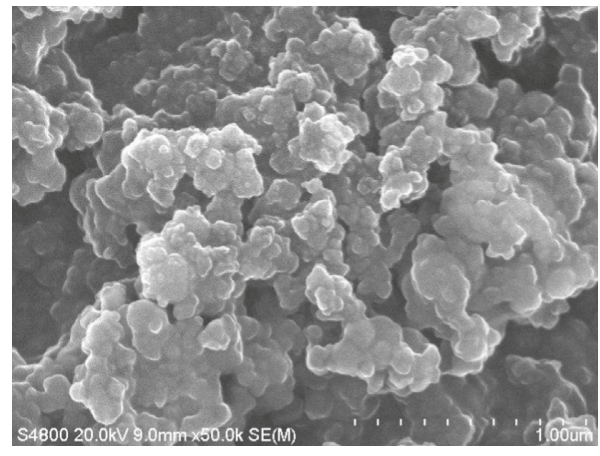

(a)

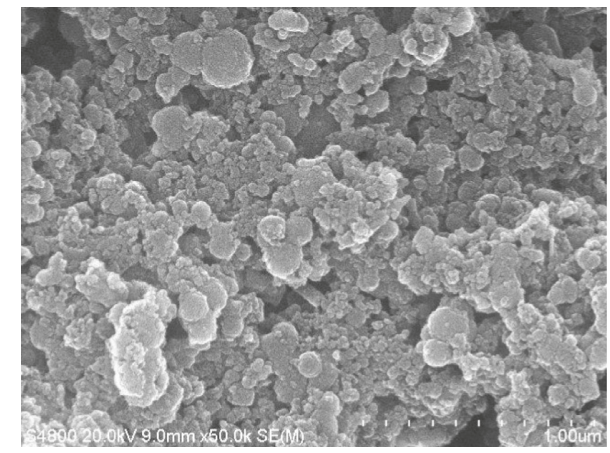

(b)

FIGURE 6: SEM micrographs of 14-day cured solidified sludge with different binder formulation. (a) 20\% PC. (b) $20 \%$ PC $+10 \%$ CFA. 
respectively. A great quantity of smooth spherical particles exists in the CFA, and they were primarily fly ash glassy spheres, acting as lubricating agent, helping to improve the rheological properties of fresh paste before setting [50,51]. Compared with Figure 6(a), the microstructure of the sample in Figure 6(b) showed a clear change. A high concentration of white globule of C-S-H was found in a denser structure, and these results corresponded to those of $\mathrm{Li}$ and Poon [36]. The CFA is believed to have pozzolanic reaction after the age of 3 days as blended with PC, forming geopolymer gel and filling between the inner portion of unreacted fly ash spheres as well as the gap of particles, thus resulting in higher densification of the matrix [51]. Recent research reveals that the main hydrate of cement and fly ash, calcium silicate hydrate (C-S-H), adopts two distinct morphologies: a low density C-S-H at the surface of cement and fly ash particles and a high density C-S-H deeper into the particles [52]. However, as shown in Figure 6(a), the gel structure of solidified matrix was loose and the density was reduced, which may increase the permeability and ionic diffusion of heavy metals in the solidified matrix. As shown in Figure 5, the leaching concentration of the sample solidified with $20 \% \mathrm{PC}+10 \% \mathrm{CFA}(1.3 \mathrm{mg} / \mathrm{L})$ is lower than that solidified with $20 \%$ PC $(6.1 \mathrm{mg} / \mathrm{L})$. Consequently, CFA can improve cement packing, block capillary pores, and reduce the permeability of heavy metals in the samples.

\section{Conclusions}

This study has provided a feasible strategy for the utilization of electroplating sludge as the subgrade backfill materials. PC and CFA were acted as curing agents in the S/S treatment of electroplating sludge. It concluded that all the studied parameters (PC content, curing time, water content, and $\mathrm{CFA} / \mathrm{PC}$ ratio) dramatically affect the effectiveness of the $\mathrm{S} / \mathrm{S}$ process.

The UCS of stabilized sludge with $0 \%$ water content meets the highway construction technical specification and increased fast with the increase of cement content, curing time, and CFA/PC ratio. The increment in strength for cement/coal fly ash-treated samples could be largely due to the main hydrate of cement and fly ash, a high density C-S-H deeper into the cement and fly ash particles, helping to achieve a tighter pore structure and greater intensity for cement-solidified mixtures. The water content produces a detrimental effect on the UCS of cement-solidified sludge, which retarded the development of strength or even reduced the final strength. This can be explained that the higher water content increases the lubrication between sludge particles and reduces the friction force. In terms of the leaching test results, it was shown that CFA can act as a filler to plug capillary pores and reduce the permeability of heavy metals in the samples.

\section{Data Availability}

We declare that all the data presented in the manuscript were obtained from laboratory tests at Soochow University in
Suzhou, China. All the laboratory testing data were presented in the figures and the tables in the manuscript. We will be very pleased to share our all the raw data. If needed, please contact us via email: pxshi@suda.edu.cn.

\section{Conflicts of Interest}

The authors declare that they have no conflicts of interest.

\section{Acknowledgments}

This study was supported by the National Natural Science Foundation of China (51778386 and 51708377), Natural Science Foundation of Jiangsu Province (BK20170339 and BK20160320), and project from Jiangsu Provincial Department of Housing, Urban-Rural Development (2016ZD18 and 2017ZD002).

\section{References}

[1] I. C. Chou, Y. M. Kuo, C. Lin, J. W. Wang, C. T. Wang, and G. P. Chang-Chien, "Electroplating sludge metal recovering with vitrification using mineral powder additive," Resources, Conservation and Recycling, vol. 58, pp. 45-49, 2012.

[2] M. Zhang, C. Chen, L. Mao, and Q. Wu, "Use of electroplating sludge in production of fired clay bricks: characterization and environmental risk evaluation," Construction and Building Materials, vol. 159, pp. 27-36, 2018.

[3] C. Zhang, J. Song, J. Zhang, J. Zhang, J. Xing, and D. Hu, "Understanding and application of an electroplating sludgederived catalyst with an active texture for improved no reduction," Science of the Total Environment, vol. 631-632, pp. 308-316, 2018.

[4] H. Lyu, Y. Gong, J. Tang, Y. Huang, and Q. Wang, "Immobilization of heavy metals in electroplating sludge by biochar and iron sulfide," Environmental Science and Pollution Research, vol. 23, no. 14, pp. 14472-14488, 2016.

[5] Q. Tang, F. Gu, Y. Zhang, Y. Q. Zhang, and J. L. Mo, "Impact of biological clogging on the barrier performance of landfill liners," Journal of Environmental Management, vol. 222, pp. 44-53, 2018.

[6] Q. Tang, H. J. Kim, K. Endo, T. Katsumi, and T. Inui, "Size effect on lysimeter test evaluating the properties of construction and demolition waste leachate," Soils and Foundations, vol. 55, no. 4, pp. 720-736, 2015.

[7] Q. Tang, T. Katsumi, T. Inui, and Z. Z. Li, "Membrane behavior of bentonite amended compacted clay," Soils and Foundations, vol. 54, no. 3, pp. 329-344, 2014.

[8] L. Q. Mao, R. Z. Tang, Y. C. Wang, Y. N. Guo, P. Su, and W. Y. Zhang, "Stabilization of electroplating sludge with iron sludge by thermal treatment via incorporating heavy metals into spinel phase," Journal of Cleaner Production, vol. 187, no. 20, pp. 616-624, 2018.

[9] S. Ucaroglu and I. Talinli, "Recovery and safer disposal of phosphate coating sludge by solidification/stabilization," Journal of Environmental Management, vol. 105, pp. 131-137, 2012.

[10] W. Y. Xia, Y. J. Du, K. R. Reddy, and Y. S. Feng, "Solidification/stabilization of $\mathrm{Pb}, \mathrm{Zn}$ and $\mathrm{Cd}$ contaminated industrial site soil using KMP binder: strength, leaching and microstructure characterization," Journal of Materials in Civil Engineering, vol. 30, no. 6, article 04018080, 2018. 
[11] W. Y. Xia, Y. S. Feng, F. Jin, L. M. Zhang, and Y. J. Du, "Stabilization and solidification of a heavy metal contaminated site soil using a hydroxyapatite based binder," Construction and Building Materials, vol. 156, pp. 199-207, 2017.

[12] G. Qian, Y. Cao, P. Chui, and J. Tay, "Utilization of MSWI fly ash for stabilization/solidification of industrial waste sludge," Journal of Hazardous Materials, vol. 129, no. 1-3, pp. 274-281, 2006.

[13] J. Ma, Y. Zhao, J. Wang, and W. Li, "Effect of magnesium oxychloride cement on stabilization/solidification of sewage sludge," Construction and Building Materials, vol. 24, no. 1, pp. 79-83, 2010.

[14] G. E. Voglar and D. Leštan, "Equilibrium leaching of toxic elements from cement stabilized soil," Journal of Hazardous Materials, vol. 246-247, no. 4, pp. 18-25, 2013.

[15] Q. Tang, Y. Zhang, Y. Gao, and F. Gu, "Use of cementchelated solidified MSWI fly ash for pavement material: mechanical and environmental evaluations," Canadian Geotechnical Journal, vol. 54, no. 11, pp. 1553-1566, 2017.

[16] A. González, R. Navia, and N. Moreno, "Fly ashes from coal and petroleum coke combustion: current and innovative potential applications," Waste Management \& Research, vol. 27, pp. 976-987, 2009.

[17] P. Nath and P. Sarker, "Effect of fly ash on the durability properties of high strength concrete," Procedia Engineering, vol. 14, pp. 1149-1156, 2011.

[18] Z. T. Yao, X. S. Ji, P. K. Sarker, J. H. Tang, L. Q. Ge, and M. S. Xia, "A comprehensive review on the applications of coal fly ash," Earth-Science Reviews, vol. 141, pp. 105-121, 2015.

[19] Y. Chao, S. Y. Liu, and Y. F. Deng, "Experimental research for the application of mining waste in the trench cutting remixing deep wall method," Advances in Materials Science and Engineering, vol. 2015, Article ID 202848, 9 pages, 2015.

[20] Y. L. Chen, M. S. Ko, Y. C. Lai, and J. E. Chang, "Hydration and leaching characteristics of cement pastes made from electroplating sludge," Waste Management, vol. 31, no. 6, pp. 1357-1363, 2011.

[21] J. Monteny, E. Vincke, A. Beeldens et al., "Chemical, microbiological, and in situ test methods for biogenic sulfuric acid corrosion of concrete," Cement and Concrete Research, vol. 30, pp. 623-634, 2000.

[22] Q. Chen, L. Zhang, Y. Ke, C. Hills, and Y. Kang, "Influence of carbonation on the acid neutralization capacity of cements and cement-solidified/stabilized electroplating sludge," Chemosphere, vol. 74, no. 6, pp. 758-764, 2009.

[23] Y. J. Du, N. J. Jiang, S. L. Shen, and F. Jin, "Experimental investigation of influence of acid rain on leaching and hydraulic characteristics of cement-based solidified/stabilized lead contaminated clay," Journal of Hazardous Materials, vol. 225-226, no. 10, pp. 195-201, 2012.

[24] Q. Tang, Y. Liu, F. Gu, and T. Zhou, "Solidification/ stabilization of fly ash from a municipal solid waste incineration facility using Portland cement," Advances in Materials Science and Engineering, vol. 2016, Article ID 7101243, 10 pages, 2016.

[25] Q. Tang, F. Gu, Y. F. Gao, T. Inui, and T. Katsumi, "Desorption characteristics of $\mathrm{Cr}(\mathrm{III}), \mathrm{Mn}$ (II) and $\mathrm{Ni}$ (II) in contaminated soil using citric acid and citric acid containing wastewater," Soils and Foundations, vol. 58, no. 1, pp. 50-64, 2018.

[26] Y. Tang, S. W. Chan, and K. Shih, "Copper stabilization in beneficial use of waterworks sludge and copper-laden electroplating sludge for ceramic materials," Waste Management, vol. 34, no. 6, pp. 1085-1091, 2014.

[27] A. O. Babatunde and Y. Q. Zhao, "Constructive approaches toward water treatment works sludge management: an international review of beneficial reuses," Critical Reviews in Environmental Science and Technology, vol. 37, no. 2, pp. 129-164, 2007.

[28] J. J. C. Bocanegra, E. E. Mora, and G. I. C. González, "Encapsulation in ceramic material of the metals $\mathrm{Cr}, \mathrm{Ni}$, and $\mathrm{Cu}$ contained in galvanic sludge via the solidification/stabilization method," Journal of Environmental Chemical Engineering, vol. 5, no. 4, pp. 3834-3843, 2017.

[29] EN 14346, Characterization of Waste e Calculation of Dry Matter by Determination of Dry Residue or Water Content, European Norm, Germany, 2006.

[30] M. T. Montañés, R. Sáncheztovar, and M. S. Roux, “The effectiveness of the stabilization/solidification process on the leachability and toxicity of the tannery sludge chromium," Journal of Environmental Management, vol. 143, no. 10, pp. 71-79, 2014.

[31] G. Cheng, Q. Li, Z. Su, S. Sheng, and J. Fu, "Preparation, optimization, and application of sustainable ceramsite substrate from coal fly ash/waterworks sludge/oyster shell for phosphorus immobilization in constructed wetlands," Journal of Cleaner Production, vol. 175, pp. 572-581, 2018.

[32] F. Tomonori, H. Akira, D. K. Achmad, M. Norio, A. N. Huang, and K. Fukui, "Utilization of incineration fly ash from biomass power plants for zeolite synthesis from coal fly ash by microwave hydrothermal treatment," Advanced Powder Technology, vol. 29, no. 3, pp. 450-456, 2018.

[33] United States Environmental Protection Agency, US EPA Method 1311: Toxicity Characteristic Leaching Procedure, US EPA, Washington, DC, USA, 1992.

[34] A. Koening, J. N. Kay, and L. M. Wan, "Physical properties of dewatered wastewater sludge for landfilling," Water Science and Technology, vol. 34, pp. 533-540, 1996.

[35] German Federal Government, Technical Guidelines for Municipal Waste of 14 May 1993, German Federal Government, Germany, 1993, in German.

[36] J. Li and C. S. Poon, "Innovative solidification/stabilization of lead contaminated soil using incineration sewage sludge ash," Chemosphere, vol. 173, pp. 143-152, 2017.

[37] D. W. Zhang, Z. G. Cao, L. B. Fan, and Y. F. Deng, "Effect of chloride salt concentration on unconfined compression strength of cement-treated lianyungang soft marine clay," Journal of Southeast University, vol. 29, no. 1, pp. 79-83, 2013.

[38] Y. J. Du, N. J. Jiang, S. Y. Liu, F. Jin, D. N. Singh, and A. J. Puppala, "Engineering properties and microstructural characteristics of cement-stabilized zinc contaminated kaolin," Canadian Geotechnical Journal, vol. 51, pp. 289-302, 2013.

[39] D. H. Moon, J. R. Lee, D. G. Grubb, and J. H. Park, “An assessment of Portland cement, cement kiln dust and Class $\mathrm{C}$ fly ash for the immobilization of $\mathrm{Zn}$ in contaminated soils," Environmental Earth Sciences, vol. 61, pp. 1745-1750, 2010.

[40] A. R. Goodarzi and M. H. Zandi, "Assessing geo-mechanical and leaching behavior of cementesilica-fume-stabilized heavy metal-contaminated clayey soil," Environmental Earth Sciences, vol. 75, no. 10, pp. 1-17, 2016.

[41] Y. S. Wang, J. G. Dai, L. Wang, D. Tsang, and C. S. Poon, "Influence of lead on stabilization/solidification by ordinary Portland cement and magnesium phosphate cement," Chemosphere, vol. 190, pp. 90-96, 2017. 
[42] P. K. Mehta and P. J. M. Monteiro, Concrete: Microstructure, Properties, and Materials, McGraw-Hill Education, New York, NY, USA, 4th edition, 2014.

[43] P. Wang, C. S. Tang, K. Q. Sun, Z. G. Chen, S. K. Xu, and B. Shi, "Advances on solidification/stabilization of sludge disposal," Journal of Engineering Geology, vol. 24, no. 4, pp. 649-660, 2016, in Chinese.

[44] C. A. Anagnostopoulos, "Strength properties of an epoxy resin and cement-stabilized silty clay soil," Applied Clay Science, vol. 114, pp. 517-529, 2015.

[45] B. Qiao, Z. H. Zhao, S. Wang, H. X. Guo, and C. Jiang, Laboratory study on diffusion of heavy metals in cement treated dredged material," Hennan Sciencevol, 35, no. 3, pp. 452-459, 2017, in Chinese.

[46] L. Wang, B. Yan, X. Wang, C. Liu, and J. Liu, "Research on effect of different heavy metal ions on C-S-H Gel and its stability," Journal of Building Materials, vol. 17, no. 5, pp. 790-796, 2014, in Chinese.

[47] C. A. Johnson, M. Kersten, F. Ziegler, and H. C. Moor, "Leaching behaviour and solubility-controlling solid phases of heavy metals in municipal solid waste incinerator ash," Waste Management, vol. 16, pp. 129-134, 1996.

[48] A. Roy and F. K. Cartledge, "Long-term behavior of a Portland cement-electroplating sludge waste form in presence of copper nitrate," Journal of Hazardous Materials, vol. 52, pp. 265-286, 1997.

[49] L. Wang, JS. H. Kwok, DC. W. Tsang, and C. S. Poon, "Mixture design and treatment methods for recycling contaminated sediment," Journal of Hazardous Materials, vol. 283, pp. 623-632, 2015.

[50] Y. Wang, F. Han, and J. Mu, "Solidification/stabilization mechanism of $\mathrm{Pb}(\mathrm{II}), \mathrm{Cd}(\mathrm{II}), \mathrm{Mn}(\mathrm{II})$ and $\mathrm{Cr}(\mathrm{III})$ in fly ash based geopolymers," Construction and Building Materials, vol. 160, pp. 818-827, 2017.

[51] V. G. Papadakis, "Effect of fly ash on Portland cement systems Part I: low-calcium fly ash," Cement and Concrete Research, vol. 29, pp. 1727-1736, 1999.

[52] C. Li, H. Sun, and L. Li, "A review: the comparison between alkali-activated slag $(\mathrm{Si}+\mathrm{Ca})$ and metakaolin $(\mathrm{Si}+\mathrm{Al})$ cements," Cement and Concrete Research, vol. 40, pp. 1341-1349, 2010. 


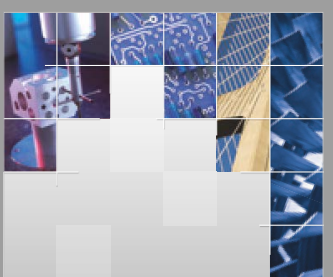

\section{Enfincering}
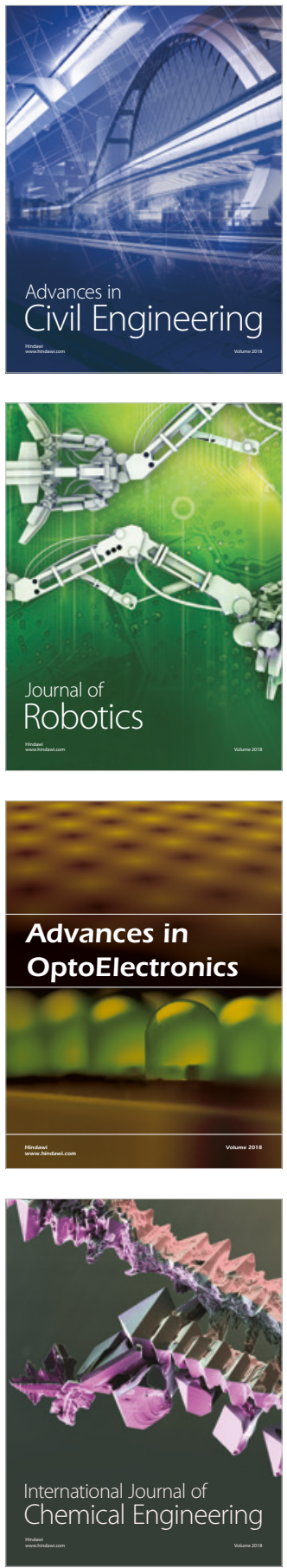

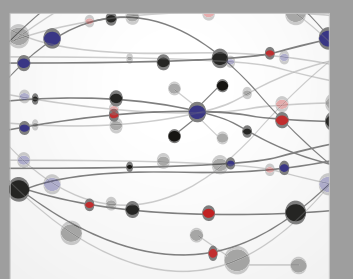

\section{Rotating \\ Machinery}

The Scientific World Journal

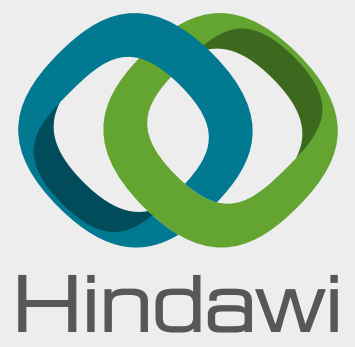

Submit your manuscripts at

www.hindawi.com
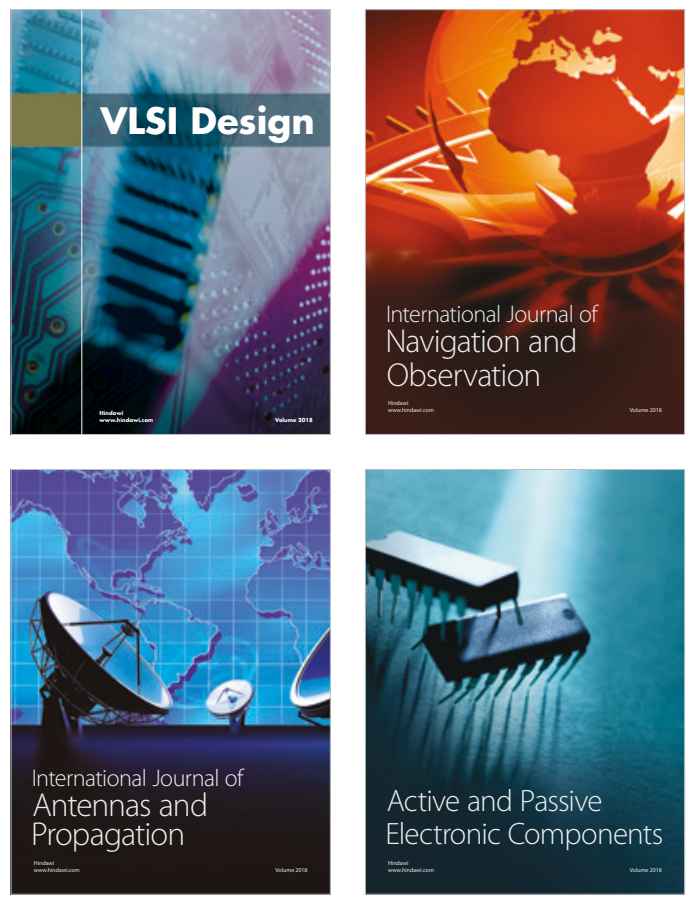
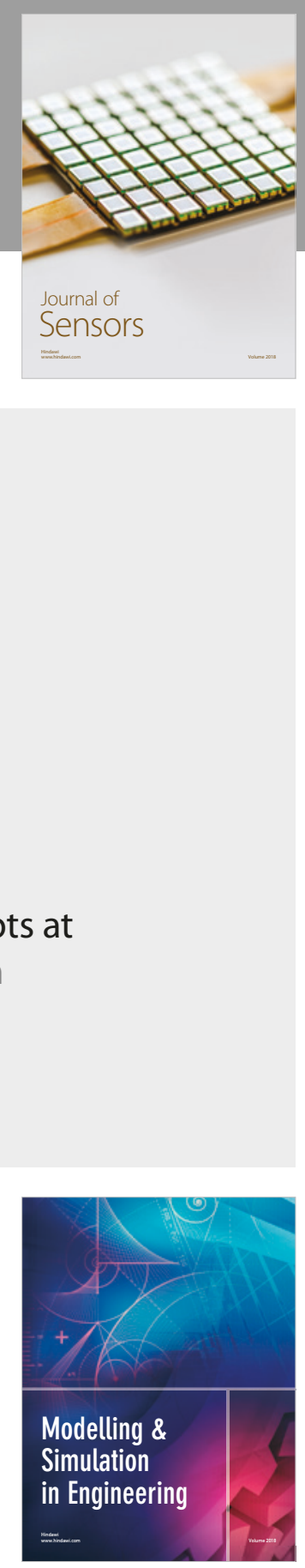

\section{Advances \\ Multimedia}
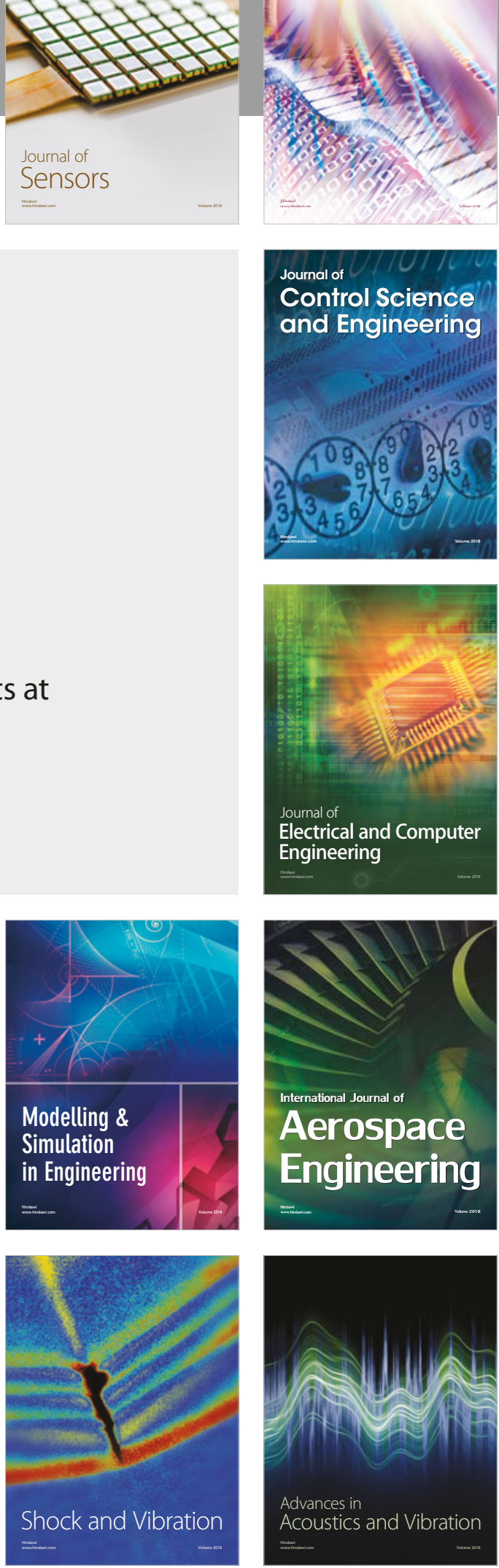